Volume 12 | Number 1| April |2021, Page 7-12/ E-ISSN: 2715-1247 dan P-ISSN: 2087-84xx

\title{
DEKADENSI MORAL REMAJA (UPAYA PEMBINAAN MORAL OLEH KELUARGA DAN SEKOLAH)
}

\author{
Lasmida Listari \\ SMA Negeri 3 Pontianak, Kalimantan Barat \\ e-mail korenpondensi : lasmida.listari74@gmail.com
}

\begin{abstract}
Abstrak : Perkembangan yang terjadi diberbagai bidang kehidupan seperti teknologi informasi dan komunikasi, munculnya berbagai sosial media yang menarik minat remaja untuk mengetahui dan mengaplikasikannya. Namun pengaruh kemajuan teknologi tersebut selain berdampak positif juga berdampak negatif pada moral remaja. Terjadi kemerosotan moral pada remaja seperti terlibat penggunaan narkoba, tawuran, penipuan, pencurian, seks bebas, intoleran, dan lain-lain. Hal ini sangat memprihatinkan dikarenakan remaja merupakan generasi penerus perjuangan bangsa. Fenomena ini cukup meresahkan masyarakat dan harus mendapat perhatian dan kerja sama dari orang tua dan sekolah serta masyarakat. Tujuan penulisan ini adalah untuk mengetahui upaya pembinaan nilai/moral pada remaja melalui keluarga sebagai unit terkecil di masyarakat dalam mensosialisasikan nilai dan norma yang berlaku di masyarakat. Keluarga yang harmonis, saling menghargai, terbuka, komunikasi positif, dan terdapat kasih sayang, maka proses sosialisasi nilai dna norma akan dapat tersampaikan pada anak/remaja dengan baik. Selain itu upaya pembinaan nilai moral pada anak dilakukan di sekolah. Sekolah yang kondusif, terdapat sikap saling menghargai, maka transinformasi nilai moral dapat diterima siswa dengan baik. Upaya ini dilakukan untuk mencegah semakin merosotnya moral remaja sehingga terbentuk perilaku remaja yang bermoral (akhlak) mulia dan bermanfaat bagi kehidupan bermasyarakat.
\end{abstract}

Kata kunci: Dekadensi Moral, Remaja

\begin{abstract}
Developments that occur in various fields of life such as information and communication technology, analysis of various social media that attract teenagers to see and apply them. However, the influence of technological advances in addition to having a positive impact also has a negative impact on adolescent morale. There is moral decline in adolescents, such as being involved in drug use, fighting, fraud, theft, free sex, intolerance, and so on. This is very concerning because adolescents are the next generation of the nation's struggle. This phenomenon is quite unsettling for the community and must receive attention and cooperation from parents and schools as well as the community. The purpose of this paper is to determine the efforts to develop values / morals in adolescents through the family as the smallest unit in society in socializing the values and norms that apply in society. A harmonious family, mutual respect, openness, positive communication, and there is love, so the socialization process of values and norms will be conveyed to children / adolescents well. In addition, efforts to foster moral values in children are carried out at school. Schools are conducive, there is mutual respect, so the transinformation of moral values can be accepted by students well. This effort is made to prevent the decline of adolescent morale so that youthful behavior is morally noble and beneficial to social life.
\end{abstract}

Keywords: Moral Decadence, Youth.

SUBMIT : 11 Maret 2021

REVIEW: 24 Maret 2021

ACCEPTED: 13 April 2021

\section{PENDAHULUAN}

Berkembangnya ilmu pengetahuan dan teknologi di era globalisasi seperti saat ini, tidak dapat kita pungkiri telah memberikan kontribusi dan pemecahan masalah dalam kehidupan manusia. Teknologi sangat berperan untuk meringankan dan memudahkan manusia dalam melakukan aktifitas dan menjalani kehidupannya. Efektifitas ruang dan waktu sebagai dampak positif dari pengetahuan dan teknologi yang maju menyebabkan hasil produktifitas manusia diberbagai bidang terus meningkat. Seperti bidang ekonomi, komunikasi, pendidikan, kesehatan, pertanian dan perkebunan, perikanan, pertambangan, dan lain-lain. 
Industrialisasi semakin maju dan berkembang sebagai wujud nyata pesatnya ilmu pengetahuan dan teknologi.

Namun dampak positif tersebut tentu berdampingan pula dengan dampak negatif pula. Tidak semua orang sanggup menerima progress tersebut sebagai item untuk menuju keberhasilan. Artinya terjadi cultural shock dalam masyarakat akibat tidak siap menerima perubahan diberbagai bidang kehidupan akibat dari majunya teknologi tersebut. Masyarakat banyak yang tidak siap menghadapi perubahan yang terjadi akibat teknologi. Demikian pula terjadinya cultural lag dalam kehidupan remaja. Ilmu pengetahuan dan teknologi yang seharusnya dimanfaatkan sebaik-baiknya untuk meningkatkan potensi, harkat serta martabat dii, namun sebaliknya menyebabkan remaja mengalami kemerosotan moral dan etika dalam bersikap dan berperilaku (dekadensi moral). M.Ali \& M. Asrori (dalam Nadia Dewi. A., 2019, h.7) menyatakan bahwa moral merupakan standar baik buruk yang ditentukan bagi individu oleh nilai-nilai sosial budaya dimana individu sebagai anggota sosial.

Masyarakat mengharapkan remaja berperilaku sesuai dengan nilai-nilai dan norma-norma yang berlaku. Seperti berakhlak mulia, sopan dan santun, sikap toleransi, tolong menolong, peka dengan kehidupan sosial orang lain yang memerlukan bantuan, tahu tugas sebagai pelajar, serta berorientasi pada masa depan. Namun akibat pengaruh teknologi yang canggih, tidak jarang banyak remaja yang terhanyut akibat pengaruh negatif budaya luar (asing) yang tidak sesuai dengan norma-norma serta adat budaya lokal. Perilaku antisosial dan sikap individualistis sering diperlihatkan remaja. Perbuatan-perbuatan melanggar hukum pun bukan menjadi berita yang aneh dan sering kita dengar. Tawuran, penipuan, curanmor, pelecehan seksual, freesex, aborsi, dan masih banyak lagi kemerosotan moral yang terjadi pada remaja. Fenomena ini membuktikan bahwa kemajuan pengetahuan dan teknologi memiliki konsekuensi logis terciptanya kondisi terjadinya dekadensi moral (Haidar Putra Daulay, 2012, h.141). Hal ini sangat memprihatinkan dan dapat mengancam kehidupan harmonis dalam masyarakat. Terlebih jika dibiarkan tanpa ada penanganan maka remaja kita akan terus mengalami kemerosotan moral. Bagaimana negara ini bisa dipimpin oleh generasi penerus yang tidak bermoral ? Sedangkan itu merupakan fondasi awal dalam berperilaku. Bagaimana pembangunan bangsa dan negara dapat berlanjut jika generasi muda kita tidak berakhlak, serta mengabaikan nilai-nilai agama ? Jumlah remaja tersebut prosentasenya memang tidak besar, namun sangat meresahkan dan dapat menjadi factor ektern bagi remaja lain dengan memengaruhi atau menularkan perilaku tidak baik.

Oleh karena itu peranan orang tua dan sekolah sangat penting dalam upaya menghidnarkan remaja dari perbuatan yang tidak baik. Karena mencegah terjadinya dekadensi moral dapat dimulai dalam lingkungan keluarga. Setelah itu sekolah sebagai lembaga formal turut berperan melanjutkan dan menguatkan upaya tersebut. Penulisan ini diharapkan dapat berkontribusi dalam memberikan informasi kepada guru sebagai tenaga pendidik di sekolah serta orang tua dalam upaya mencegah terjadinya dekadensi moral pada remaja.

\section{HASIL DAN PEMBAHASAN}

Pendidikan moral bukanlah hal yang baru dalam dunia pendidikan. Berbagai upaya dilakukan oleh orang tua dan sekolah agar anak atau remaja berperilaku sesuai dengan harapan masyarakat. Terdapat nilai dan norma yang menjadi pedoman dan aturan yang disepakati dan diataati oleh masyarakat. Kehidupan masyarakat yang sangat berharga adalah suasana aman, tentram, damai, saling kerja sama, dan tolong menolong, sikap hormat menghormati, menghargai dan toleransi. Remaja harus dibekali dengan sikapsikap tersebut. Proses transinformasi moral dapat dimulai melalui keluarga serta sekolah.

\section{Dekadensi moral}

Muhaimin (dalam M. Iskarim, 2016) menyatakan "moral memiliki pengertian yang sama dengan akhlak (khulq), character, dispotsition, budi pekerti, dan etika" (h.10). Sementara itu, Audrah Mannan (2017) menyatakan bahwa moral adalah "realitas dari kepribadian umunnya bukan hasil dari perkembangan pribadi semata, namun moral merupakan tindakan atau tingkah laku seseorang."'(h.62).

Moral menyangkut kegiatan-kegiatan manusia yang dipandang sebagai baik atau 
buruk, benar atau salah, tepat atau tidak tepat, atau menyangkut cara seseorang bertingkah laku dalam hubungannya dengan orang lain (Kohlberg dalam Mansur, 2006)

Sementara itu dekadensi moral dapat diartikan sebagai "suatu keadaan terjadinya kemerosotan moral yang bermakna bahwa individu ataupun kelompok tidak mematuhi peraturan dan tata cara yang berlaku dalam masyarakat" (Edo Dwi Cahyo, 2017, h.19)

Merosotnya moral remaja (dekadensi moral) tidak terlepas dari pengaruh teknologi informasi dan komunikasi yang semakin canggih dan terus mengalami perubahan kemajuan. Sering kita membaca atau mendengar dan menonton berita tentang remaja atau pelajar yang melakukan aksi tawuran, perkelahian, penipuan, aksi begal, mengancam, pencurian, narkoba, seks bebas, dan lain-lain. Peran media massa baik elektronik maupun cetak sebagai sarana dalam pembinaan dan memberikan pendidikan kepada masyarakat, malah terkadang menjadi pemicu terjadinya dekadensi moral remaja. disamping itu, lingkungan masyarakat tempat remaja berinteraksi juga berpengaruh besar pada pola perilaku remaja.

Lingkungan masyarakat yang sehat akan berdampak pada terbentuknya pola perilaku positif pada remaja. Sebaliknya lingkungan yang tidak baik seperti maraknya perjudian, kriminalitas, tindakan asusila, dan lain-lain dapat turut menjadikan moral remaja tersebut negatif. Menurut Lickona (2013) ada beberapa indikasi gejala merosotnya moral remaja yaitu (1) kekerasan dan tindakan anarkis, (2) Pencurian, (3)Tindakan curang, pengabaian pada aturan, (5)Tawuran antar siswa, (6) Intoleran, (7)Penggunaan bahasa yang tidak baik, (8) Kematangan seksual yang terlalu dini, (9)Sikap perusakan diri, dan (10) Penyalahgunaan narkoba.

Semua gejala tersebut sering kita dengar terjadi pada remaja. Sifatnya sudah sangat mendesak dan harus segera diambil langkahlangkah tegas dalam upaya pencegahan lebih lanjut.

\section{Remaja}

World Health Organization (WHO) mengidentifikasikan masa remaja yaitu berusia sekitar 10-19 tahun, yaitu selepas masa kanakkanak namun sebelum masa dewasa. Pada remaja terjadi pertumbuhan dan perubahan yang cepat dalam hal fisik, sosial, ekonomi, kemandirian, alat reproduksi, serta pencarian identitas diri. Sementara itu, Hurlock membagi masa remaja awal dengan usia antara 13-17 tahun dan remaja akhir antara usia 17-18 tahun.

Usia remaja memang rentan dengan pengaruh eksternal (diluar dirinya). Masa remaja oleh Hall (dalam Byod \& Bee, 2005) dalam bahasa Jerman disebut sebagai masa "strurm und drang" (storm dan stress), yaitu fase dimana remaja berusaha menjadi pribadi yang mandiri yang terkadang penuh gejolak emosi dan frustasi.

Remaja ditandai dengan berbagai karakteristik diantaranya secara psikologis ditandai dengan rasa dan perasaan, emosi yang labil dan terkadang tidak menentu. Masa ini memerlukan pendampingan dari orang tua dan lingkungan sekolah serta masyarakat. karena dikhawatirkan remaja akan terjerumus dalam perbuatan yang tidak baik.

Masa remaja merupakan masa dimana remaja sering menghadapi godaan atau pengaruh yang tidak baik dari lingkungannya terutama dari teman sepermainan. Intensitas pertemuan dan interaksi yang sering dengan teman sepermainan dapat memengaruhi pola pikir dan perilaku remaja.

\section{Pembinaan moral oleh keluarga}

Keluarga sebagai lingkungan pertama dan terutama dalam proses sosialisasi nilai dan moral pada anak. Pembentukan karakter anak sangat dipengaruhi oleh pola asuh dan didikan orang tua. Oleh sebab itu, orang tua harus memiliki dasar dalam memahami nilai dan norma yang berlaku di masyarakat. sehingga proses transformasi dan proses transinternalisasi nilai dan norma dapat berlaku maksimal.

Hendaknya terjalin komunikasi yang positif antara orang tua dan anak. Keluarga yang penuh kasih sayang, taat sebagai umat beragama, kehangatan, keterbukaan, keakraban, dan sikap saling memahami satu sama lain akan mudah dalam menanamkan sikap dan perilaku yang patuh pada nilai dan norma. Moral (akhlak) akan terbentuk sesuai harapan masyarakat. Anak akan berusaha menjaga suasana kondusif dalam keluarganya dengan berusaha untuk patuh terhadap nilai moral yang berlaku. 
Sebaliknya komunikasi yang buruk, tidak adanya keakraban, ketegangan psikis, kurangnya kasih sayang dapat menyebabkan terjadinya kemerosotan moral pada anak atau remaja. Setidaknya ada empat tipe parenting styles yang dikemukakan oleh Baumrind dalam Diah Ningrum (2015) yaitu authoritarian parenting, authoritative parenting, neglectful parenting, dan indulgent parenting. Authoritarian parenting, meurpakan pola pengasuhan berupa larangan, hukuman, berupa perintah yang harus ditaati oleh anak, serta menghargai usaha orang tua (Santrock,2010). Orang tua dengan tipe asuh seperti ini akan menuntuk anak memenuhi keinginannya tanpa memikirkan atau mengutamakan kepentingan psikologis anak.

Sebaliknya authoritative parenting cenderung memberikan motivasi anak menjadi pribadi yang mandiri namun tetap dikontrol oleh orang tua dengan batassan-batasan (Santrock, 2010). Dalam pola ini, orang tua memberikan bimbingan yang baik kepada anak, mengabaikan hukuman dan lebih supportive dari tindakan disiplin yang diambil, serta mengutamakan komunikasi dua arah dan bernilai positif.

Berikutnya dalam Neglectful parenting orang tua tidak terlibat sama sekali dalam pengasuhan anak-anaknya, menolak untuk bertanggung jawab sebagai orang tua dan terhadap perkembangan anak-anaknya (Carr, 2009). Sedangkan untuk indulgent parenting, orang tua terlibat sepenuhnya dalam kehidupan anak-anaknya namun tidak ada control dari orang tua, artinya anak dilepas tanpa pengawasan dan tidak memerlukan tanggung jawab atas semua perbuatan anakanaknya (Carr, 2009).

Sebuah penelitian terhadap anak-anak usia 3-12 tahun, didapatkan data bahwa anak-anak di bawah pengasuhan orang tua secara authoritative parenting cenderung percaya diri, mempunyai tenggang rasa, kompeten, mudah bekerja sama, dan mature (matang). Anak dalam posa asuh tersebut juga cenderung memiliki prestasi, memiliki kemampuan (kompeten) dalam menghadapi masalah, sedikit melakukan kesalahan, dan hanya sedikit yang mengalami masalah psikologis (Diah Ningrum, 2015).

Penanaman nilai dan norma serta moral pada remaja dapat dilakukan dengan cara authoritative parenting. Transinternalisasi dari orang tua kepada anak merupakan upaya yang sangat tepat untuk dilakukan selain transinformasi. Mengingat remaja cenderung bisa meniru perilaku orang-orang disekelilingnya. Oleh sebab itu, orang tua dapat menjadi model dalam berperilaku sesuai dengan nilai dan norma yang berlaku di masyarakat. Diharapkan remaja dapat meniru perilaku positif tersebut sehingga tidak terjadi kemerosotan moral remaja.

\section{Pembinaan moral remaja di sekolah}

Selain keluarga, pembinaan moral, nilai dan norma dilakukan pula di lingkungan sekolah. Sebagai lembaga formal di bidang pendidikan, sekolah menjadi harapan terwujudnya pendidikan nilai dan norma serta menciptakan pembelajar yang diantaranya adalah remaja menjadi insan yang berakhlak mulia. Untuk itu, perlu disusun suatu rancangan kurikulum yang mengarah pada pembinaan moral pada setiap mata pelajaran dan jenjang pendidikan. Idealnya pembinaan moral dilakukan sejak dini agar ketika remaja anak sudah terbiasa dengan perilaku positif dalam menjalani hubungannya dengan kehidupan baik dilingkungan keluarga, sekolah maupun masyarakat.

Dilihat dari segi makro, pendidikan merupakan ujung tombak bagi kemajuan bangsa. Artinya semakin baik layanan pendidikan pada pembelajar maka output dari satuan pendidikan tersebut juga akan baik. Seperti yang dirumuskan oleh Bapak Ki Hajar Dewantara (Sitria, Welly \& Zulaeha, 2017, h.319) mengenai pendidikan bahwa "pendidikan umumnya berarti daya upaya untuk memajukan budi pekerti (karakter, kekuatan batin), pikiran (intellect), dan jasmani anak-anak selaras dengan alam dan masyarakatnya"

Pendidikan idealnya menciptakan suatu perubahan dari hasil belajar pembelajar (siswa) kearah lebih baik. mandiri, mampu berdaya saing, pantang menyerah dan bermanfaat bagi masyarakat diantaranya patuh dan taat pada norma serta mempertahankan perilaku (akhlak) positif yang dipelajari selama masa pendidikan di sekolah. Terlebih para pembelajar atau remaja tersebut suatu saat akan berperan dalam masyarakat dengan segala masalah dan realitas kehidupan yang lebih kompleks. Lingkungan sekolah harus dapat menciptakan suasana kondusif agar 
proses pembelajaran dalam mencapai nilainilai positif pembentukan karakter pembelajar dapat tercapai.

Semua unsur sekolah dalam hal ini kepala sekolah, guru staf, dan semua bertanggung jawab dalam pengolahan pendidikan nilai moral dan karakter. Pendidikan nilai moral dapat dikatakan suatu usaha secara sadar yang dilakukan oleh orang dewasa yang terencana untuk memberikan kesempatan kepada peserta didik (anak, remaja, generasi penerus) menanamkan ke-Tuhanan, nilai-nilai estetik dan etik, nilai baik dan buruk, benar dan salah, mengenai perbuatan, sikap dan kewajiban; akhlak mulia, budi pekerti luhur agar mencapai kedewasaannya dan bertanggung jawab (Ahmad Nawawi, 2011, h.123).

Pelajar berada dalam lingkungan pendidikan dengan orang-orang dewasa disekelilingnya. Segala perilaku orang-orang dewasa tersebut yaitu guru, staf, dan semua unsur yang terdapat di sekolah. Begitu pentingnya pendidikan nilai/moral agama dan budi pekerti bagi remaja, karena akan menjadi bekal mereka dalam berperilaku sehari-hari. Guru hendaknya memberikan contoh nyata dalam berperilaku positif kepada pembelajar (siswa).

\section{KESIMPULAN}

Dekadensi moral (kemerosotan moral) pada remaja menjadi masalah yang sangat memprihatinkan dalam kehidupan kita. Remaja yang seharusnya menjadi generasi penerus perjuangan bangsa dan melanjutkan proses pembangunan bangsa dan negara malah terjerumus dalam perbuatan yang tidak baik dan bahkan mengancam ketentraman dan keharmonisan dalam kehidupan bermasyarakat. Oleh karena itu pendidikan nilai/moral atau pembinaan moral pada remaja merupakan tugas bersama antara orang tua, sekolah dan masyarakat. Upaya ini dilakukan agar remaja dapat berperilaku sesuai dengan nilai-nilai dan norma-norma yang berlaku dalam masyarakat.

Dalam keluarga penanaman nilai/moral merupakan fondasi penting bagi terbentuknya karakter remaja sehingga mereka dapat menjalani kehidupannya di masyarakat dengan sikap dan perilaku positif. Karena suatu saat remaja sebagai generasi penerus akan ikut berperan dalam masyarakat.
Keluarga yang harmonis dan akrab, saling bekerja sama, komunikasi yang positif, dan saling mendukung, maka remaja akan mudah meninternalisasikan nilai moral dalam kehidupan pribadinya dan siap berperan di masyarakat. Sebaliknya keluarga yang tidak harmonis, komunikasi negatif, tidak ada keakraban, orang tua melepaskan tanggung jawab, maka remaja dapat mengalami kemerosotan moral akibat pengaruh eksternal seperti sosial media, pergaulan bebas, narkoba, hedonism, konsumerisme, dan perbuatan antisosial. Orang tua berperan penting dalam mengontrol pergaulan remaja, serta harus menjadi contoh tauladan bagi anak atau remaja dalam kehidupan sehari-hari.

Selain keluarga sekolah sebagai lembaga pendidikan juga berperan penting dalam pembentukan karakter remaja. kepala sekolah, guru, staf, dan semua unsur yang terdapat di dalamnya hendaknya memberikan pemahaman, didikan, serta contoh berperilaku sesuai nilai moral. Karakter remaja sebagai pelajar dapat terbentuk ketika berada di sekolah. Namun hendaknya suasana belajar dapat diciptakan kondusif, tenang, tertib, dan menyenangkan. Sehingga proses sosialisasi nilai moral dalam upaya pembinaan dan penanaman nilai moral pada siswa atau remaja dapat dilaksanakan dengan maksimal dan menghasilkan outpun siswa yang berakhlak mulia, taat dan patuh pada ajaran agamanya, berperilaku positif, dan patuh pada nilai dan norma yang berlaku dalam masyarakat.

\section{DAFTAR RUJUKAN}

Afrita, N.D. (2020). Dekadensi Moral dan Peran Tokoh Masyarakat dalam Menguatkan Perilaku Kagamaan di KElurahan Duseun Kebun Kecamatan Batang Asam Kabupaten Tanjung Jabung Barat. Skripsi. Fakultas Tarbiyah dan Keguruan Universitas Islam Negeri Sultan Thaha Saifuddin Jambi.

Cahyo, Edo. D. (2017). Pendidikan Karakter Guna Menanggulangi Dekadensi Moral yang Terjadi Pada Siswa Sekolah Dasar. EduHumaniora: Jurnal Pendidikan Dasar, vol. 9 (1); 16-26.

Daulay, Haidar. P. (2012). Pendidikan Islam dalam Sistem Pendidikan Nasional di Indonesia. Jakarta: Kencana 
Volume 12 | Number 1| April |2021, Page 7-12/ E-ISSN: 2715-1247 dan P-ISSN: 2087-84xx

Iskarim, M. (2016). Dekadensi Moral di Kalangan Pelajar (Revitalisa Strategi PAI dalam Menumbuhkan Moralitas Generasi Bangsa). Edukasia Islamika, vol. 1(1); 1-20.

Lickona, Thomas. (2013). Mendidik Untuk Membentuk Karakter. Jakarta: Remaja Rosdakarya.

Mansur, Amril. (2006). Implementasi Klarifikasi Nilai Dalam Pembelajaran dan Fungsionalisasi Etika Islam. Jurnal Ilmiah Keislaman, Vol. 5(1) ; 44-69.
Nawawi, Ahmad. (2011). Pentingnya Pendidikan Nilai Moral Bagi Generasi Penerus, INSANIA, vol. 6(2); 119-133.

Ningrum, Diah. (2015). Kemerosotan Moral di Kalangan Remaja:sebuah Penelitian Mengenai Styles dan Pengajaran Adab Diah Ningrum Sekolah Menengah Islam Terpadu (SMIT) Al Marjan, UNISIA, vol. 37(82); 18-30.

Santrock, J. W. (2010). Child Development. (12th Edn). New York: McGraw-Hill 